\title{
On the weak compactness of the product of some operators
}

\author{
Belmesnaoui AqZzouz, Othman AboutAfail and Aziz Elbour
}

\author{
ABSTRACT. \\ compact). \\ DÉPARTEMENT D'ECONOMIE \\ UNIVERSITÉ MOHAMMED V-SOUISSI \\ FACUlté des SCIENCES ECONOMIQUeS, JuRIDIQUeS ET Sociales \\ B.P. 5295, SAlaAlJADidA, MOROCCO \\ E-mail address: baqz zouz @hotmail.com \\ DÉPARTEMENT DE MATHÉMATIQUES \\ UNIVERSITÉ IBN TOFAIL \\ FACULTÉ DES SCIENCES \\ B.P. 133, KÉNITRA, MOROCCO
}

We study the weak compactness of the product of two operators when one of them is order weakly compact (resp. semi-compact, b-weakly 